\title{
Petr Gal
}

Institute for Research and Developement of Education

Charles University in Prague

(iD) https://orcid.org/0000-0003-3095-6663

$\triangle$ petriirigal@gmail.com

\section{DROPOUT IN POST-COMMUNIST COUNTRIES OF CENTRAL EUROPE (THE VISEGRAD GROUP)}

D0I: $10.24917 / y c e e .2020 .11 .70-80$

\begin{abstract}
:
Early school leaving (dropout) is a problem in all education systems. In 2010 the European Commission launched the Europe 2020 strategy which included a list of measures to reduce the school dropout rates in the EU countries. The aim of this paper is to analyse the issue of dropout in upper secondary education (ISCED 3 ) in the education systems of four post-communist Central European states (Czech Republic, Hungary, Poland, and Slovakia). The paper describes and compares the education systems of these countries and the important changes of their education policies after entering the EU. The analysis of Eurostat data shows that despite the decline of the average early school leaving rate in the EU countries from 13.8\% to 10.2\% between 2010 and 2019, the Czech Republic, Hungary, and Slovakia are among the four member states whose dropout rates are rising. Through an overview of research studies, this paper also identifies the dominant topics and "weak spots" related to early school leaving in these countries.

Keywords: $\quad$ early school leaving, dropout, upper secondary education, secondary school, Visegrad Group, Czech Republic, Hungary, Poland, Slovakia.

Abstrakt: $\quad$ Przedwczesne kończenie nauki jest problemem we wszystkich systemach edukacji. W 2010 roku Komisja Europejska przedstawiła strategię „Europa 2020”, która zawiera listę środków mających na celu zmniejszenie odsetka uczniów przedwcześnie kończących edukację w krajach UE. Celem artykułu jest analiza problemu przerywania nauki w szkołach średnich (ISCED 3) w systemach edukacji czterech postkomunistycznych państw Europy Środkowej (Czechy, Węgry, Polska i Słowacja). We wstępie artykułu opisuję i porównuję systemy edukacyjne tych krajów oraz ważne zmiany, jakie zaszły w polityce edukacyjnej po wejściu tych państw do UE. Z analizy danych Eurostatu wynika, że pomimo spadku średniego wskaźnika przedwczesnego kończenia nauki w krajach UE z 13,8\% do 10,2\% w latach 2010-2019 w Czechach, na Węgrzech i na Słowacji te wskaźniki rosną. Prowadzone analizy pozwalają na identyfikację mechanizmów odpowiedzialnych za powstanie odpadu szkolnego w badanych państwach.

Słowa kluczowe: porzucanie nauki szkolnej, wczesne kończenie nauki, szkoła średnia, Grupa Wyszehradzka, Czechy, Węgry, Polska, Słowacja.
\end{abstract}

The study was supported by the Charles University Grant Agency through the project Dropout of Czech High School Students in the Context of the Maturita Exam (No. 40282I). 
— arly school leaving (dropout) is an important - phenomenon in terms of research and education policies as it has a significant impact on the life of the individual and societal costs. In the EU, almost $60 \%$ of early school leavers are unemployed while this is only the case of $15 \%$ of youth with an upper secondary education certificate in the same age cohort (Eurostat, 2016). This illustrates the importance of education for successful labour market transitions.

The subject of this paper is the phenomenon of early school leaving from secondary schools in four post-communist countries of Central Europe: the Czech Republic, Hungary, Poland, and Slovakia. These countries were chosen because of their similar historical development and geopolitical orientation. At the end of the 1980 s, all of them underwent the collapse of communist state establishment, transition to the liberal-democratic systems ${ }^{2}$, and breaking away from the influence of the USSR. In the second half of the 1990s, they first became members of the Organisation for Economic Co-Operation and Development (OECD) ${ }^{3}$, at the turn of the millennium entered the North Atlantic Treaty Organization (NATO) ${ }^{4}$, and in 2004 were accepted among the member states of the European Union (EU) in the fifth wave of enlargement. In 1991, they established the Visegrad Group (today called also the Visegrad Four) with the aim of strengthening cooperation among the states in the region.

The aim of this paper is to describe the phenomenon of early school leaving on the example of countries which have a lot in common, yet at the same time can deal with specific educational problems and have different approaches to similar challenges in education policies. The paper first describes the

2 However, according to the EU institutions and political scientists (Krastev, 2016; Rupnik, 2018; Zielonka, Rupnik, 2020), since approx. 2010 Hungary and Poland have undergone evident systemic changes weakening their liberal-democratic establishment.

3 The Czech Republic in 1995, Hungary and Poland in 1996, Slovakia in 2000.

4 The Czech Republic, Hungary and Poland in 1999, Slovakia in 2004. structure of the upper education systems (ISCED 3 ) in the Visegrad Group countries, then defines early school leaving theoretically and presents an analysis of how the main topics are reflected in literature.

\section{Upper Secondary Education in the Visegrad Group Countries}

\subsection{Historical Context}

At the beginning of the 1990s, the education systems of the Visegrad Group were in a similar starting position, inherited from communism. It was characterized by central management, unified structure of education (Walterová, Janík, 2006), dominant position of vocational education and training and professional/technical education, and low proportion of population with tertiary education (Mikiewicz, 20II).

Political changes, the recovery of private business and the large number of professionally educated, experienced and yet "cheap" workers attracted foreign industry corporations to the post-communist countries. Especially car factories and related engineering companies gained a strong position. According to Śćepanović (2020), the industry lobby gained a considerable influence on the labour market and the education system, which led to (I) big industry employers sustaining the demand for labourer job positions, (2) supporting vocational education with the result that (3) especially the Czech but also Hungarian and Slovak education systems underwent the smallest change after 1989 compared with other countries in Central and Eastern Europe.

\subsection{Current Structure and System of Secondary Schools}

Table I shows secondary education indicators of the Visegrad Group countries. The national systems are described below. 


\begin{tabular}{|c|c|c|c|c|}
\hline & Czech Republic & Hungary & Poland $^{5}$ & Slovakia \\
\hline $\begin{array}{l}\text { length of compulsory } \\
\text { education }\end{array}$ & $5-15$ years & $3-16$ years & 6-15 (18) years & $6-16$ years \\
\hline $\begin{array}{l}\text { usual age of entering } \\
\text { secondary school }\end{array}$ & 15 years & 14 years & 15 years & 15 years \\
\hline usual graduation age & $18-19$ years & $18-19$ years & $18-20$ years & $18-19$ years \\
\hline $\begin{array}{l}\text { conditions for entering } \\
\text { secondary school }\end{array}$ & $\begin{array}{l}\text { unified (state) entering } \\
\text { exam (study programs } \\
\text { with school-leaving exam- } \\
\text { ination); } \\
\text { school entering exam, } \\
\text { other school criteria (study } \\
\text { programs without the } \\
\text { school-leaving examina- } \\
\text { tion); } \\
\text { talent exam (conserva- } \\
\text { toires). }\end{array}$ & $\begin{array}{l}\text { school entering exam, } \\
\text { other school criteria } \\
\text { (secondary school pro- } \\
\text { grams); } \\
\text { central exam } \\
\text { (long-term grammar } \\
\text { schools). }\end{array}$ & $\begin{array}{l}\text { results of the final exam in } \\
\text { the final (eighth) grade of } \\
\text { elementary school }\end{array}$ & $\begin{array}{l}\text { compulsory entering } \\
\text { exam, other school criteria } \\
\text { (study programs with } \\
\text { school-leaving examina- } \\
\text { tion); } \\
\text { school criteria (study } \\
\text { programs without } \\
\text { school-leaving examina- } \\
\text { tion); } \\
\text { talent exam (conserva- } \\
\text { toires). }\end{array}$ \\
\hline $\begin{array}{l}\text { a) academically orient- } \\
\text { ed school (grammar } \\
\text { school) }\end{array}$ & $\begin{array}{l}\text { 1) grammar school } \\
\text { (gymnázium); } \\
\text { 2) } 4 \text { years, long-term } \\
\text { programs; } \\
\text { 3) school-leaving exam- } \\
\text { ination. }\end{array}$ & $\begin{array}{l}\text { 1) grammar school (gim- } \\
\text { názium); } \\
\text { 2) } 4 \text { years, } 5 \text { years; } \\
\text { 3) school-leaving exam- } \\
\text { ination. }\end{array}$ & $\begin{array}{l}\text { 1) general lyceum (liceum } \\
\text { ogólnokształcace); } \\
\text { 2) } 4 \text { years; } \\
\text { 3) school-leaving exam- } \\
\text { ination. }\end{array}$ & $\begin{array}{l}\text { 1) grammar school } \\
\text { (gymnázium); } \\
\text { 2) } 4 \text { years, long-term } \\
\text { programs; } \\
\text { 3) school-leaving exam- } \\
\text { ination. }\end{array}$ \\
\hline $\begin{array}{l}\text { b) technical/vocational } \\
\text { upper secondary school }\end{array}$ & $\begin{array}{l}\text { 1) vocational upper sec- } \\
\text { ondary school, lyceum; } \\
\text { 2) } 4 \text { years; } \\
\text { 3) school-leaving exam- } \\
\text { ination. }\end{array}$ & $\begin{array}{l}\text { 1) vocational upper secon- } \\
\text { dary school (technikum; } \\
\text { szakgimnázium); } \\
\text { 2) } 4 \text { years; } \\
\text { 3) school-leaving exami- } \\
\text { nation. }\end{array}$ & $\begin{array}{l}\text { 1) vocational upper secon- } \\
\text { dary school (technikum); } \\
\text { 2) } 5 \text { years; } \\
\text { 3) possibility to obtain } \\
\text { both school-leaving exa- } \\
\text { mination and professional } \\
\text { qualification. }\end{array}$ & $\begin{array}{l}\text { 1) vocational upper secon- } \\
\text { dary school, sports upper } \\
\text { secondary school; } \\
\text { 2) } 4 \text { years; } \\
\text { 3) school-leaving exami- } \\
\text { nation. }\end{array}$ \\
\hline $\begin{array}{l}\text { c) vocational school/ } \\
\text { training }\end{array}$ & $\begin{array}{l}\text { 1) secondary vocational } \\
\text { school; } \\
\text { 2) 2-year or 3-year pro- } \\
\text { grams; } \\
\text { 3) training (vocational } \\
\text { certificate); } \\
\text { 4) follow-up 2-year } \\
\text { school-leaving exam } \\
\text { program. }\end{array}$ & $\begin{array}{l}\text { 1) vocational school } \\
\text { (szakközépiskola) with } \\
\text { a dual system; } \\
\text { 2) } 3 \text { years; } \\
\text { 3) professional qualifi- } \\
\text { cation; } \\
\text { 4) follow-up 2-year } \\
\text { school-leaving exam } \\
\text { program. }\end{array}$ & $\begin{array}{l}\text { 1) secondary vocational } \\
\text { school (szkoła branżowa } \\
\text { Istopnia; /l stopnia); } \\
\text { 2) } 3 \text { years; } \\
\text { 3) professional qualifi- } \\
\text { cation; } \\
\text { 4) follow-up 2-year } \\
\text { school-leaving exam } \\
\text { program. }\end{array}$ & $\begin{array}{l}\text { 1) secondary vocational } \\
\text { school } \\
\text { 2) 2-year or 3-year pro- } \\
\text { grams; } \\
\text { 3) training (vocational } \\
\text { certificate); } \\
\text { 4) follow-up 2-year } \\
\text { school-leaving exam } \\
\text { program. }\end{array}$ \\
\hline $\begin{array}{l}\text { d) special secondary } \\
\text { schools }\end{array}$ & $\begin{array}{l}\text { 1) conservatory; } \\
\text { 2) 8-year or 6-year pro- } \\
\text { grams; } \\
\text { 3) school-leaving exami- } \\
\text { nation } \\
\text { graduation examination. }\end{array}$ & $\begin{array}{l}\text { 1) vocational school for } \\
\text { special education (szaki- } \\
\text { skola); } \\
\text { 2) } 2 \text { years; } \\
\text { 3) professional qualifi- } \\
\text { cation. }\end{array}$ & $\begin{array}{l}\text { 1) special school for pro- } \\
\text { fessional training (szkoła } \\
\text { specjalna przysposabiajaca } \\
\text { do pracy); } \\
\text { 2) } 3 \text { years; } \\
\text { 3) certification of gradu- } \\
\text { ation. }\end{array}$ & $\begin{array}{l}\text { 1) conservatory; } \\
\text { 2) 7-year or 4-year pro- } \\
\text { grams; } \\
\text { 3) school-leaving exami- } \\
\text { nation } \\
\text { graduation examination. }\end{array}$ \\
\hline
\end{tabular}

Note: The information about each type of school is in the following order: 1) name of the school; 2) standard length of study; 3) graduation qualification; 4) other information.

Note 2: The table was made by the author using Eurydice data and education documents of each country. 
Czech Republic. Secondary education with school-leaving exam can be obtained at general upper secondary schools (grammar schools), vocational upper secondary schools, or lyceums. It is a prerequisite to entering tertiary education. Vocational schools offer 2-year and 3-year programs with a vocational certificate. Graduates of 3-year vocational schools can then study in a follow-up 2-year program with the school-leaving exam. Conservatory is a specific type of secondary school offering lower and upper secondary education as well as tertiary training in art. Lower secondary education can be obtained also at 8 -year or 6-year programs at grammar schools ${ }^{6}$.

Traditionally, high percentage of Czech pupils, about $75 \%$, enter vocational education and training, while the EU average is about 50\% (Eurostat, n.d.).

Hungary. Upper secondary education is offered by general secondary schools or grammar schools (gimnázium), vocational upper secondary schools (technikum, szakgimnázium), vocational schools (szakközépiskola), and vocational schools for special education (szakiskola). Grammar schools can offer long-term programs starting from the fifth or seventh grades of elementary school.

Gimnázium offers 4-year general education programs with preparation for the school-leaving examination, which is prerequisite to entering a university. Vocational upper secondary schools offer 4-year general education programs with a professional specialization concluded with a school-leaving exam. Vocational schools also offer additional 2-year lower secondary education programs for adult students who did not finish elementary school. After graduation they can

5 The table shows the new structure of Polish upper secondary education after the reform which came into effect for secondary schools in the school year 2019/2020.

6 The fact that some pupils leave elementary schools for these academically oriented schools provokes discussions about the impact of 8-year and 6-year grammar school programs on inequalities in Czech education system (cf. Straková, 2006; Sucháček, 20I4). continue studying 2-year or 4-year programs. Graduates of vocational schools receive a graduation diploma and can continue at 2-year programs with school-leaving examination (Eurydice, 2020a).

Poland. The length of study at academically oriented general education lyceums (liceum ogólnoksztatcace) is 4 years and it is concluded with a school-leaving examination, which has included a standardized (state) part since 2005 . The length of study at vocational secondary schools (technikum) is 5 years. Students at vocational schools have the opportunity to pass a school-leaving examination and obtain a vocational (professional) qualification at the same time, which means that even those who fail the examination still receive a certification of vocational graduation. This concept increases the interest in vocational education (Praag et al., 20I8).

Students who failed in the national curriculum assessment when finishing elementary school usually continue at vocational schools (szkota branżowa) which offer two-level education. After graduating from the first (3-year) level, a student receives a qualification diploma and can study further, as in the Czech Republic and Slovakia, in a follow-up 2-year school-leaving examination program (second level). Despite the fact that Polish compulsory school attendance ends with graduation from elementary school, students are obliged to continue in compulsory education (obowiazek nauki) until the age of i8 (Eurydice, $2020 b$ ). They can choose between studying at a secondary school and starting practical training with an employer combining work with additional qualification courses.

Slovakia. After nine years of elementary school, students enter general, vocational, or art education. 4-year grammar schools (gymnázium) offer general education ending, since 2008 , with a unified state school-leaving examination, which is prerequisite to entering tertiary education. Grammar schools can offer also long-term programs (5-years, 8-years). 4-year programs with 
school-leaving examinations are offered by vocational upper secondary schools (stredné odborné školy) and sport upper secondary school (stredné športové školy). Art education is provided by conservatories (konzervatórium) in similar programs as in the Czech Republic. Vocational schools offer 2-year and 3-year programs with a vocational certificate. Graduates of 3-year programs of vocational schools can further study in a follow-up 2-year program with school-leaving exam (Eurydice, 2020c).

\section{Early School Leaving}

\subsection{Theoretical Definition}

Early school leaving is generally defined as ending the school attendance without obtaining upper secondary education (ISCED 3; Csereklye, 2008; Lamb, Markussen, Teese et al., 20ı; OECD, 20I2). Surveys within the European context refer to these individuals as early school leavers. They are students under the age of 24 (in most systems secondary education ends between the age of 17 and 20) who left education prematurely, achieved maximum lower secondary education (ISCED 2), and do not continue studying (Lamb, Markussen, Teese et al., 20II).

Relevant literature uses the terms dropout and early school leaving (ESL) for this phenomenon (Lamb, Markussen, Teese et al., 20ı ; NairzWirth, Gitschthaler, 2019; OECD, 2012). As both terms (dropout, early school leaving) can be considered equivalent, they will be used as synonyms in this paper.

Early school leaving is a problem in all education systems. In most OECD countries, graduation from upper secondary education is considered to be the minimal level of qualification as it is prerequisite to entering university and work at well-paid job positions. Surveys in different countries show that those individuals who do not obtain upper secondary education are more often unemployed and have lower income and economic capital (Rumberger, Lamb, 2003) and worse health (Owens, 2004) than those from upper secondary schools and higher schools.

\subsection{Dropout in the EU and the Visegrad Group}

In 2010, the European Commission launched a strategic plan for the next ro years - the Europe 2020 strategy. One of the main goals in the area of education was to reduce the average early school leaving rates in the EU to less than $10 \%$ (European Commission, 2010). The document included a list of measures to be taken to achieve this aim which were to be incorporated to the national strategies of the member states

The current data (Eurostat, 2020a) show that the aim has been achieved at least partially because between 2010 and 2019 the average dropout rate in the EU decreased from $13.8 \%$ to $10.2 \%$. This trend is significantly influenced by the decline of dropout rate in some of the South European countries (e.g. in Spain from $28.2 \%$ to $17.3 \%$, in Portugal from $28.3 \%$ to $10.6 \%$, and in Italy from I $8.6 \%$ to $13.5 \%)$.

The Visegrad Group countries traditionally belonged (except for the "average" Hungary) to the countries with a high number of successful secondary education graduates (Andrei, Teodorescu, Oancea, 2or ; Praag et al., 20I8). However, the comparison of the data in table 2 shows a change in this trend which occurred in the last decade.

While in Poland the long-term dropout rate between 2010 and 2019 was stable, in the Czech Republic, Hungary, and Slovakia it increased. These three countries together with Bulgaria are the only EU states where the early school leaving rates have increased since launching the Europe 2020 strategy. According to Eurostat (2O2Oa), the percentage of early school leavers in the Czech Republic in the year of introducing the state 
Table 2

Dropout Rate in the Studied Countries between 2010 and 2019 (in \%)

\begin{tabular}{|c|c|c|c|c|c|c|c|c|c|c|c|c|}
\hline Country & $\begin{array}{l}\text { Order } \\
\text { according to } \\
\text { the dropout } \\
\text { rate (EU27, } \\
2010 \text { ) }\end{array}$ & 2010 & 2011 & 2012 & 2013 & 2014 & 2015 & 2016 & 2017 & 2018 & 2019 & $\begin{array}{l}\text { Order } \\
\text { according to } \\
\text { the dropout } \\
\text { rate (EU27, } \\
\text { 2019) }\end{array}$ \\
\hline EU27 (average) & & 13.8 & 13.2 & 12.6 & 11.8 & 11.1 & 11.0 & 10.6 & 10.5 & 10.5 & 10.2 & \\
\hline $\begin{array}{l}\text { Czech } \\
\text { Republic }\end{array}$ & $2^{\text {nd }}$ & 4.9 & 4.9 & 5.5 & 5.4 & 5.5 & 6.2 & 6.6 & 6.7 & 6.2 & 6.7 & $8^{\text {th }}$ \\
\hline Hungary & $12^{\text {th }}$ & 10.8 & 11.4 & 11.8 & 11.9 & 11.4 & 11.6 & 12.4 & 12.5 & 12.5 & 11.8 & $22^{\text {nd }}$ \\
\hline Poland & $5^{\text {th }}$ & 5.4 & 5.6 & 5.7 & 5.6 & 5.4 & 5.3 & 5.2 & 5 & 4.8 & 5.2 & $6^{\text {th }}$ \\
\hline Slovakia & $1^{\text {st }}$ & 4.7 & 5.1 & 5.3 & 6.4 & 6.7 & 6.9 & 7.4 & 9.3 & 8.6 & 8.3 & $14^{\text {th }}$ \\
\hline
\end{tabular}

school leaving examination (201I) was $4.9 \%$, in $20145.5 \%$, and in $20196.7 \%$. Despite the fact that this increase is the fourth highest in the EU, the Czech Republic still belongs to the top third of EU states with the lowest dropout rates. Hungary has made a commitment in the Europe 2020 strategy to reduce its early school leaving rates to IO\% by 2020 . Yet, in 2019 II.8\% of students were leaving Hungarian schools early. In comparison with other states, Slovakia changed for the worst as it went from the best position with the lowest dropout rate to the average position.

Poland as the only one of the studied countries maintains a stable dropout rate around $5 \%$ and so is among the top quarter of the EU states. Early school leaving is therefore not viewed as a serious problem in education (Mikiewicz, 2011, p. 173). The length of the compulsory education and the screening of students during entering secondary school by the national curriculum assessment can be one of the reasons for the low dropout rate. Mikiewicz (20II) points out that while Polish education system is successful in having a large number of students obtaining secondary education, students from lower socioeconomic backgrounds usually enter vocational schools which provide lower quality preparation for tertiary education compared to general secondary schools. Thus, the children replicate the educational paths of their parents, and the low dropout rate is in fact only a seeming success.

\section{Main Issues of Early School Leaving}

The literature review of Scopus and Google Scholar databases showed that early school leaving from secondary schools in the Visegrad Group countries is a topic discussed only in a few surveys ${ }^{7}$. In the analysed texts focusing on the studied countries there are several issues that are mentioned repeatedly and thus can be considered important.

7 In the Czech context, it is mainly state institutions that monitor the early school leaving issue in terms of its rate and frequency (e.g. ČŠI, 20I8; Lebeda et al., 2020). The perspectives of professionals (representatives of schools, NGOs, authorities, and others) on the causes of dropout (Hloušková, 20I4) and possible interventions (Bubíková, Úlovcová, Viceníková et al., 2006; Trhlíková, Úlovcová, 20ıо; Trhlíková, 2012; Trhlíková, 2013) are monitored in the long-term perspective as well. In the wider context, surveys on inequalities in education (Matějů, Straková, Veselý, 2010) and inter-school mobility (Dvořák, Vyhnálek, 2019) also contribute to the clarification of possible causes of early school leaving. 


\section{Regional Inequalities}

In every country there are significant regional differences in terms of the quality of education and the dropout rate (these two variables usually corelate) which are related to worse socioeconomic situation of these regions. Usually, they are peripheral areas.

The most affected regions are North Hungary (Észak-Magyarország), with the dropout rate as high as $15 \%$, and South Transdanubia (DélDunántúl), with 10-15\% rate (Fehérvári, 2015). The regions of North Poland and East Slovakia reach similar numbers (Eurostat, 2020b). In the Czech Republic we can find similar situation in the North-West regions along the border. According to Prokop (2019, p. 68), it is mostly the systemic problem of education policies which is unable to ensure similar quality of schools in all regions:

Karlovy Vary and Ústí nad Labem regions have similar results of PISA tests as Bulgaria or Malaysia while in richer regions we are [as Czechia] above the European average. Around $17 \%$ of children in poor regions never achieve secondary education whereas in Prague and richer regions it is between 2 and $4 \%$... the families' social status explains less than a half of the regional differences in the education results. The rest is the responsibility of the local education system.

\section{Educational Segregation of Minorities and Foreigners}

In the observed countries, the issue of inclusion of students from minorities is reduced mainly to Roma students. Even though it is not the only minority, this group has a dominant position in the literature review. Jarkovská et al. (2015) explain this "invisibilization" of foreigners in contrast to highlighting Roma students' differences in the Czech education policy as a result of insufficient experience with education of foreigners.
Nevertheless, according to the authors, the children of foreigners, similar to Roma students, are usually not offered good quality education.

Unsuccessful inclusion of Roma minority into the educational mainstream has been a serious and long-term problem. In the Czech, Hungarian, and Slovak education, there are still segregated "Romani" schools, and Roma students are placed disproportionally more often in special schools, which, according to Messing (2017), limits the chances of young Roma population at the beginning of their school attendance to have further (quality) education and deprives them of the opportunity to establish relationships with schoolmates from the majority (non-Roma) population.

Scereklye (2008) uses the example of Hungarian Roma people to show that ethnicity is a quite precise indicator of dropout in Hungarian society. According to the author, dropout is not connected primarily with low success at studies. What is significant, there are the values shared by the family. The results of the survey show that at home Roma students are not motivated to study, and in their communities they do not see any examples of social mobility which would happen in consequence to studying. Therefore, they do not consider education to be a path to a successful life. However, minority students themselves see causes of their early school leaving in the school environment and mention discrimination, dissatisfaction at school, inadequate expectations of teachers, and related low success at studies as the main reasons (Scereklye, 2008). On the other hand, Hungarian teachers (Szabó, 20I8) believe that the students who bear the biggest responsibility for early school leaving ${ }^{8}$ while the institutions are the least responsible. According to Prokop (2019), Czech Roma people face an educational handicap too as they study at special

8 The main cause of dropouts from the teachers' perspectives is the deviant behavior of students (skipping classes, drinking alcohol, abusing drugs, or aggressiveness). 
schools disproportionally more often than other students, and as a result they have few attractive study programs to choose from.

\section{Vocational Schools}

Academically oriented schools (grammar schools) in the studied countries have the lowest dropout rate, only units of percentages. Technical/professional schools have the highest rate of early school leaving (e.g. more than a quarter of these students in the Czech Republic and Hungary do not complete their education; Úlovcová, 2006) ${ }^{9}$.

According to Czech researchers (Hlad'o, 20I2; Trhlíková, 20I2; Úlovcová, 2006), the high dropout rate in vocational schools is the result of wrong choice of secondary school, which is caused by inappropriate career counselling at elementary schools. When choosing a secondary school, pupils often do not get the feedback relevant to their interests, knowledge, and skills, which would help them find a suitable program. They choose a program they lack information about. The students then solve this poor choice by changing the program or by leaving education (Dvořák, Vyhnálek, 2019).

In the Czech context, the choice of unsuitable school is related to the missing screening of students before entering school. In the conclusion to its thematic report on vocational schools, the Czech School Inspectorate (2018) emphasizes that the programs with school-leaving examination with high failure rate accept almost all applicants $^{10}$ regardless of their previous study results and their potential to study. According to the authors (2018, p. 7), more thorough selection of students entering the schools would undoubtedly and significantly reduce the risk of their later failure during the studies or when graduating.

9 According to Hlad'o and Šlapalová (2018), such dropout rate is not uncommon in the European context.

10 In the school year 2016/2017, the observed schools accepted $93 \%$ of applicants.
Hungarian and Slovak vocational schools face a similar problem.

For this reason, since 2013 Hungarian technical (vocational) schools have provided a "dual" education system which, starting from the first year, combines practical training at workplace with theoretical subjects. The concept of earlier connection of studies with the labour market is to reduce the high dropout rate in the first year of study (Bükki, 2019, pp. 16-17).

On the other hand, Polish education system uses results of the national curriculum assessment in the last grade of elementary school as a thorough selection tool. Thus, students with insufficient score are not accepted to programs with school-leaving examination, which can have impact on the low rate of early school leaving from Polish vocational schools.

\section{Discussion and Conclusion}

Education and professional training are the main driving force of economic growth, higher standards of living, and socially cohesive society. The number of job positions requiring only low qualifications is constantly declining and due to the rapid technological development, the labour market needs more highly qualified employees (Szabó, 2018).

The analyses of surveys and documents identified three "weak spots" of the studied countries' education systems: regional inequalities, educational segregation of minorities, and high early school leaving rate at professional (vocational) schools. This reduction was motivated by the effort to identify the issues common to all the Visegrad Group countries. This "narrow" focus on the three issues is the main limitation of this text, which is why they will be now briefly expanded.

According to Rumberger (2004, 20II), early school leaving cannot be considered to be a result of a specific and clearly defined factor as it is more of the final phase of a dynamic, cumulative, and 
multilevel process. According to the author, it is inaccurate to consider the general phenomena mentioned above (e.g. ethnicity, regional inequalities, and differing quality of schools) as the direct causes of dropout because they are "only" a few of many factors influencing the dropout process. This procedural concept of dropout has been backed by some of surveys (e.g. Nand, 2017; Ogresta, Rezo, Kožljan et al., 2020).

The process of dropout is initiated by a breaking point, the result of which is leaving secondary school. These breaking points can be for example uninspiring family environment, health and personal problems (Trhlíková, Úlovcová, Vojtěch, 2006), high absenteeism, or low grades (Vacek, Pacnerová, Menclová, 2008).

The situation in the Visegrad Group states shows that it is difficult to implement suitable measures to counter early school leaving. Despite the fact that average early school leaving rate in EU states decreased from $13.8 \%$ to $10.2 \%$ between 2010 and 2019, the Czech Republic, Hungary, and Slovakia (and Bulgaria) are the only EU states with an increasing dropout rate. In Poland, the only Visegrad Group country where students do not take entrance exams when entering upper secondary education, the dropout rate keeps steadily at around $5 \%$. The traditionally high value of education in Poland and the school reform in 2017 can be an inspiring example of a national upper secondary education policy.

Clear and elaborate preventive and intervening actions should be taken in order to decrease early school leaving rate labour (Szabó, 20I8). However, in the national goals of the Europe 2020 strategy the Visegrad Group countries did not include any complex strategies to prevent dropout. They only took partial measures (Praag et al., 2018). It is evident from the EU documents that only Hungary and Poland created support programs focusing on early school leaving prevention for some types of secondary schools. Hungarian career counselling program springboard helps students choose a suitable study program using coaching, getting to know the professions at workplace, and developing their work skills (Cedefop, 2016, p. 54). In Poland the unemployed below 30 can use state support to return to education (Cedefop, 2016, p. 75). Even though these programs can support some groups of students at the risk of failing in their studies to a certain degree, they cannot substitute the absence of systemic strategies for decreasing the early school leaving rate at secondary schools.

All the above-mentioned facts make dropout a socially significant phenomenon. To be able to understand it, it is necessary to research not only the current situation in each country, but also to critically assess how effective the implemented preventive, intervening, and compensatory measures are.

\section{Acknowledgements}

I would like to thank both reviewers. Their critical and detailed comments helped me to detect insufficiencies of the original text. I would like to express my gratitude to professor Eliška Walterová (Charles University in Prague) for her critical and detailed comments of this text.

\section{Bibliography}

Andrei, T., Teodorescu, D., \& Oancea, B. (2011). Characteristics and causes of school dropout in the countries of the European Union [0nline]. Procedia - Social And Behavioral Sciences, 28, 328-332. https://doi. org/10.1016/j.sbspro.2011.11.062.

Bubíková, M., Úlovcová, H., Viceníková, T., \& Hytha, P. (2006). Předčasné odchody mladých lidí ze středního vzdělávání: Rozsah, problémy, príčiny a možnosti prevence [Early school leaving of young people in secondary education: The extend, problems, causes and possibilities of prevention]. Prague: Národní ústav pro vzdělávání.

Bükki, E. (2019). Vocational education and training in Europe: Hungary. Cedefop ReferNet VET in Europe reports 2018. Available at: http:// libserver.cedefop.europa.eu/vetelib/2019/Vocational_Education_Training_Europ e_Hungary_2018_Cedefop_ReferNet.pdf.

Cedefop (2016). Leaving education early: putting vocational education and training centre stage. Volume ll: evaluating policy impact. Luxembourg: Publications Office. Available at: http://dx.doi.org/10.2801/967263.

Csereklye, E. (2008). Reasons for school failure among ethnic minority students. Practice And Theory In Systems Of Education, 3(3-4), 87-92. 
ČŠl. (2018). Vzdělávání ve středních školách s vysokou mírou neúspěšnosti žáků ve společné cásti maturitní zkoušky. Tematická zpráva [Education at secondary schools with the students' high failure rate in the common part of school leaving examination. Thematic report]. Available at: https://www.csicr.cz/Csicr/media/Prilohy/PDF_el._publikace/ TZ-Vzdelavani-v-neuspesnych-skolach-s-obory-vzdelani-s-MZ.pdf.

Dvořák, D., \& Vyhnálek, J. (2019). Meziškolní mobilita žáků středních škol v České republice [Inter-school mobility of secondary school students in the Czech Republic]. Pedagogika, 69(2). https://doi. org/10.14712/23362189.2018.856.

Eurostat. (2016). Educational attainment level and transition from education to work (EU-LFS). Available at: https://ec.europa.eu/eurostat/cache/ metadata/en/edat1_esms.htm

Gesthuizen.

Eurostat. (2020a). Early leavers from education and training. Available at: https://ec.europa.eu/eurostat/statistics-explained/index.php/ Early_leavers_from_education_and_training.

Eurostat. (2020b). Eurostat regional yearbook 2020. Available at: https:// ec.europa.eu/eurostat/documents/3217494/11348978/KS-HA-20001-EN-N.pdf.

Eurostat. (n.d.). EU policy in the field of vocational education and training Available at: https://ec.europa.eu/education/policies/eu-policy-in-the-field-of-vocational-education-and-training-vet_en.

European Commission. (2010). Europe 2020: A strategy for smart, sustainable and inclusive growth. Luxembourg: Office for Official Publications of the European Communities.

Eurydice. (2020a). Hungary Overview. Available at: https://eacea.ec.europa. eu/national-policies/eurydice/content/hungary_en.

Eurydice. (2020b). Poland Overview. Available at: https://eacea.ec.europa. eu/national-policies/eurydice/content/poland_en.

Eurydice. (2020c). Slovakia Overview. Available at: https://eacea.ec.europa. eu/national-policies/eurydice/content/slovakia_en.

Fehérvári, A. (2015): Lemorzsolódás és a korai iskolaelhagyás trendjei [Dropping out and trends of early school-leaving]. Neveléstudomány, (3) $3,31-47$.

Hlado, P. (2012). Profesní orientace adolescentů: poznatky z teorií a výzkumů. Brno: Konvoj.

Hlad’o, P., \& Šlapalová, K. (2018). Důvody žáků středních škol pro opakovaný přstup na jinou školu. Výzkumná zpráva pro Jihomoravský kraj [The reasons of secondary school students for repeated change of schools]. Brno: FF MU.

Hloušková, L. (2014). Mám základní vzdělání. Příčiny a důsledky předčasných odchodů ze studia a ze vzdělávání [I have elementary education. Causes and consequences of early school leaving]. Studia paedagogica, 19(2), 11-38.

Jarkovská, L., Lišková, K., Obrovská, J., \& Souralová, A. (2015). Etnická rozmanitost ve škole: stejnost v různosti [Ethnic diversity at school: equality in heterogeneity]. Prague: Portál.

Krastev, I. (2016). Liberalism's failure to deliver [Online]. Journal Of Democracy, 27(1), 35-38. https://doi.org/10.1353/jod.2016.0001.

Lamb, S., Markussen, E., Teese, R., Polesel, J., \& Sandberg, N. (Eds.). School dropout andcompletion. Dordrecht: Springer Netherlands. https://doi. org/10.1007/978-90-481-9763-7.

Lebeda, T., Lysek, J., Marek, D., Folwarczný, R., Navrátilová, A., Soukop, M., et al. (2020). Zpráva - Hlavní město Praha: výsledky žáků, nerovnosti, struktura a charakteristika soustavy, faktory ovlivňujicí vzdèlávaci výsledky [The report - the Capital city of Prague: students' results, inequalities, structure and character of the system, factors influencing the study results]. Prague: Česká školní inspekce.

Matějů, P., Straková, J., \& Veselý, A. (Eds.). (2010). Nerovnosti ve vzdělávání: od měrení $k$ řešení [Inequalities in education: from measurement to solution]. Prague: Sociologické nakladatelství (SLON).

Messing, V. (2017). Differentiation in the making: Consequences of school segregation of Roma in the (zech Republic, Hungary, and Slovakia [Online]. European Education, 49(1), 89-103. https://doi.org/10.1080 /10564934.2017.1280336.

Mikiewicz P. (2011). School dropout in secondary education: The case of Poland. In: Lamb, S., Markussen, E., Teese, R., Polesel, J., \& Sandberg, N. (Eds.). School dropout and completion. Dordrecht: Springer Netherlands. https://doi.org/10.1007/978-90-481-9763-7.

Nairz-Wirth, E., \& Gitschthaler, M. (2019). Relational analysis of the phenomenon of early school leaving: A habitus typology [0nline]. European Educational Research Journal. https://doi.org/10.1177/1474904119893916.

Nand, L. (2017). Applying ecological systems theory to understand the determinants of early school leaving and second-chance education in a socio-economically disadvantaged area in Sydney, Australia (Disertační práce). Sydney: Western Sydney University. https://researchdirect. westernsydney.edu.au/islandora/object/uws\%3A44416.

OECD. (2012). Education at a Glance 2012. https://doi.org/10.1787/eag_ highlights-2012-en.

Ogresta, J., Rezo, I., Kožljan, P., Paré, M. H., \& Ajduković, M. (2020). Why do we drop out? Typology of dropping out of high school. Youth \& Society, 52(6), 1-21.

Owens, J. (2004). A review of the social and non-market returns to education. Education and Learning Network, Wales.

Praag, L. V., Nouwen, W., Caudenberg, R. V., Clycq, N., \& Timmerman, C. (2018). Comparative perspectives on early school leaving in the European Union. London: Routledge, Taylor \& Francis Group.

Prokop, D. (2019). Slepé skvrny: o chudobě, vzdělávání, populismu a dalšich výzvách české společnosti [Blind spots: about poverty, education, populism and other challenges of (zech society]. Brno: Host.

Rumberger, R. W., \& Lamb, S. P. (2003). The early employment and further education experiences of high school dropouts: a comparative study of the United States and Australia. Economics OfEducation Review, 22(4), 353-366. https://doi.org/10.1016/S0272-7757(02)00038-9.

Rumberger, R. W. (2004). Why students drop out of school. In G. Orfield (Ed.), Dropouts in America: Confronting the Graduation Rate Crisis (s. 131-156). Cambridge, MA: Harvard Education Press.

Rumberger, R. W. (2011). Dropping out: Why students drop out of high school and what can be done about it. Cambridge, MA: Harvard University Press.

Rupnik, J. (2018). The crisis of liberalism [0nline]. Journal Of Democracy, 29(3), 24-38. https://doi.org/10.1353/jod.2018.0042.

Straková, J. (2006). Víceletá gymnázia a jejich role v reprodukci vzdělanostních nerovností [Long-term grammar schools and their role in reproduction of inequalities in education]. In P. Matěju \& J. Straková (Eds.), Nerovné šance na vzdělání: Vzdělanostní nerovnosti v České republice [Unequal chances for education: Inequalities in education in the Czech Republic] (s. 194-219). Prague: Academia.

Sucháček, P. (2014). The feud over multi-year gymnasia: historical context and empirical data [0nline]. Studia Paedagogica, 19(3), 139-154. https:// doi.org/10.5817/SP2014-3-8.

Szabó, C. M. (2018). Causes of early school leaving in secondary education. Journal of Applied Technical and Educational Sciences, 8(4), 54-76. https://doi.org/10.24368/jates.v8i4.65. 
Šćepanović, V. (2020). Skills on wheels: Raising industry involvement in vocational training in the Czech Republic, Slovakia and Hungary [Online]. In A. Covarrubias V. \& S. M. Ramírez Perez (Eds.), New Frontiers of the Automobile Industry (s. 401-428). Cham: Springer International Publishing. https://doi.org/10.1007/978-3-030-18881-8_16.

Trhlíková, J. (2012). Předčasnéodchody ze vzdělávánína strèedních školách. Kvalitativní analýza rozhovorů sexperty a príklady dobrých praxí [Early school leaving at secondary schools. Qualitative analysis of interviews with experts and examples of good practice]. Prague: Národní ústav pro vzdělávání.

Trhlíková, J. (2013). Předčasné odchody žáků ze středních škol: Názory pracovníků škol a úradů práce na nástroje prevence a intervence [Early school leaving at secondary schools: Opinions of school employees and Labour Offices on prevention and intervention tools]. Prague: Národní ústav pro vzdělávání.

Trhlíková, J., \& Úlovcová, H. (2010). Vliv rodinného zázemí na předčasné odchody ze vzdělávání a dlouhodobou nezaměstnanost mladých lidí [The influence of family background on early school leaving and long-term unemployment of young people]. In P. Matějů, J. Straková, \& A. Veselý (Eds.), Nerovnosti ve vzděláváni: od měrení k řešení [Inequalities in education: from measurement to solution] (s. 151-179). Prague: Sociologické nakladatelství (SLON).

Trhlíková, J., Úlovcová, H., \& Vojtěch, J. (2006). Sociální aspekty dlouhodobé nezaměstnanosti mladých lidí s nizkou úrovní vzděláni: šetření mladistvých, kteří jsou po ukončení základni školy evidováni jako uchazeči o zaměstnání na úradech práce ČR [Social aspects of long-term unemployment of young people with low level of education: survey among the youngsters registered as job seekers at Labour Offices in the [zech Republic after finishing elementary school]. Prague: Národní ústav odborného vzdělávání.

Úlovcová, H. (2006). Předčasné odchody mladých lidíze středního vzděláváni: rozsah, problémy, príčiny, možnosti prevence [Early school leaving of young people in secondary education: The extend, problems, causes and possibilities of prevention]. Prague: NÚOV.

Vacek, J., Pacnerová, H., \& Menclová, M. (2008). Příciny prèedčasných odchodů ze středního školního vzdělávání u žáků ze sociokulturnè znevýhodněného prostředí, průzkum pro projekt PROPOS [Causes of early school leaving in secondary education of students from socio-culturally disadvantaged environment, a survey for the PROPOS project]. Prague: Centrum adiktologie a IPPP.

Walterová, E., \& Janík, T. (2006). Transformace vzdělávacích systémů zemí visegradské skupiny: srovnávací analýza [The transformation of education systems in the Visegrad Group countries: comparative analyses] [Online]. Orbis Scholae, o(1), 13-29. https://doi. org/10.14712/23363177.2018.132.

Zielonka, J., \& Rupnik, J. (2020). From revolution to 'counter-revolution': Democracy in Central and Eastern Europe 30 years on [Online]. Europe-Asia Studies, 72(6), 1073-1099. https://doi.org/10.1080/096681 36.2020.1784394. 